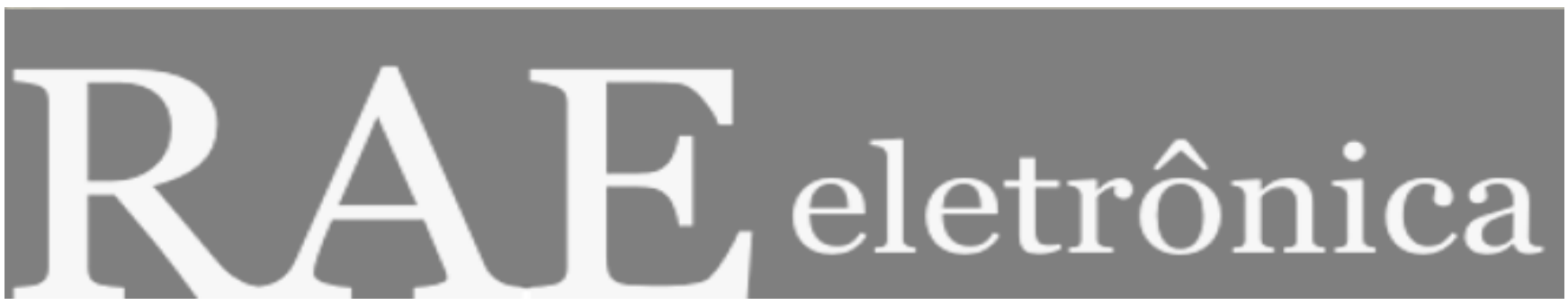

PRODUCT DEVELOPMENT AND RISK PARTNERSHIP: A CASE STUDY

Por

Érico Veras Marques

Luiz Carlos Di Serio

Mauro Furtado

RAE-eletrônica, Volume 1, Número 1, jan-jun/2002.

http://www.rae.com.br/eletronica/index.cfm?FuseAction=Artigo $\& I D=1279 \&$ Secao=OPERA/LOGI $\&$ Volume $=1 \&$ Numero $=$ $1 \& A n o=2002$

CCopyright, 2002, RAE-eletrônica. Todos os direitos, inclusive de tradução, são reservados. É permitido citar parte de artigos sem autorização prévia desde que seja identificada a fonte. A reprodução total de artigos é proibida. Os artigos só devem ser usados para uso pessoal e nãocomercial. Em caso de dúvidas, consulte a redação: redacao@,rae.com.br.

A RAE-eletrônica é a revista on-line da FGV-EAESP, totalmente aberta e criada com o objetivo de agilizar a veiculação de trabalhos inéditos. Lançada em janeiro de 2002, com perfil acadêmico, é dedicada a professores, pesquisadores e estudantes. Para mais informações consulte o site www.rae.com.br/eletronica.

RAE-eletrônica

ISSN 1676-5648

(C)2002 Editora: Fundação Getulio Vargas - Escola de Administração

de Empresas de São Paulo.

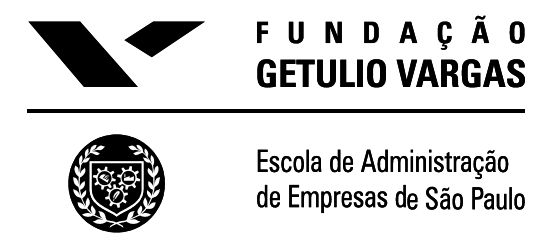




\section{PRODUCT DEVELOPMENT AND RISK PARTNERSHIP: A CASE STUDY}

\section{Érico Veras Marques}

Doutorando em Administração de Empresas da FGV-EAESP.

E-mail:emarques@gvmail.br

\section{Luiz Carlos Di Serio}

Professor do Departamento de Administração da Produção e de Operações

e Industriais da FGV - EAESP.

E-mail: ldiserio@fgvsp.br

\section{Mauro Furtado}

Gerente de Programas, Embraer S.A. - Mestre em Administração de Empresas

pela FGV/EAESP.

E-mail:mafurtad@uol.com.br

Endereço: Av Brig Faria Lima, 2170 - S.J. Campos - SP, 12.227-901

Interesses de Pesquisa: Gestão de Projetos, Estruturas Organizacionais.

\section{RESUMO}

A indústria aeronáutica sempre se caracterizou por possui altos custos de investimentos em capital, pessoal, tempo e tecnologia no processo de desenvolvimento de novos produtos.

A forte concorrência no mercado de transporte aéreo tem pressionado os fabricantes na construção de novos modelos de aeronaves dentro de um espectro de produtos que atendam as necessidades especificas de cada segmento do mercado, ou seja produtos cada vez mais customizados.

$\mathrm{O}$ uso do desenvolvimento integrado de produtos através de parcerias de risco tem sido usado por algumas industrias com o objetivo de minimizar os investimentos acima citados, assim como redução do ciclo de desenvolvimento de produtos, tendo como conseqüência a redução do time to market.

O presente trabalho tem como objetivo analisar, a partir de diversos modelos de competitividade, como a industria aeronáutica brasileira esta fazendo uso do desenvolvimento integrado de produtos com parceiras de riscos efetivamente ser um diferencial no mercado

\section{ABSTRACT}

The aeronautical industry has always been known for having high investment costs concerning capital, personnel, time and technology as it engages in the process of developing new products.

The strong competition in the air transport market has been putting pressure on the manufacturers to build new aircraft models in a range of products which assists the specific needs of each segment of the market, that is, always more customized products.

The integrated development of products through risk partnership has been used by some industries aiming to minimize the investments mentioned above, as well as to reduce the cycle of products development, what results in reduction of time to market.

This work aims to analyze, considering various models of competitiviness, how the Brazilian aeronautical industry is making the integrated development with risk partnerships a real distinguishing feature in the market. 


\section{PALAVRAS CHAVES}

Parceria de Risco, Desenvolvimento de Produto, Competitividade

\section{KEY WORDS}

Risk Partnership, Product Development, Competitiviness 


\section{INTRODUCTION}

The aeronautical industry has always been known for having high investment costs concerning capital, personnel, time and technology as it engages in the process of developing new products.

The strong competition in the air transport market has been putting pressure on the manufacturers to build new aircraft models in a range of products which assists the specific needs of each segment of the market, that is, always more customized products.

The the integrated development of products through risk partnership has been used by some industries aiming to minimize the investments mentioned above, as well as to reduce the cycle of products development, what results in reduction of time to market.

This work aims to analyze, considering various models of competitivity, how the Brazilian aeronautical industry is making the integrated development with risk partnerships a real distinguishing feature in the market.

In order to carry out this analysis the work will be divided into three parts. The first phase consists of the theoretical aspects of competitivity and product development. The second phase consists of the development of a case study in a company with significant participation in the Brazilian aeronautical industry. The third and last part consists of the analysis of the case based on the theoretical reference built up.

\section{PRODUCTS DEVELOPMENT}

Urban (1993:01) states that "New products are crucial to successful growth and increased profits in many organizations".

The importance of developing new products is also noticed by Rosenau ( 1996 ) as he claims that new products are critical to the success of the organizations due to the level of competitivity in the markets, the technological development, the changes in the consumers needs and other aspects.

Some authors such as Bruce (1995) say that the product develpoment is fundamental for economic growth since it is through this aspect that the industrialized countries manage to obtain and support their riches and prosperity.

Among the various questions concerning the development of new products we can highlight the following one : How can we produce successful products?

Rosenau ( 1996 ) defines some critical factors of success in the development of new products, among which are these :

Developing a differentiated product which brings unique values and benefits to the client.

Being market oriented .

Undertaking the predevelopment homework upfront.

Getting sharp, early product definition before development begins. 
Execution quality.

Having the necessary structural organization.

Following the market speed without losing quality.

Synergy and familiarity with the product .

According to Urban ( 1993 ), the development of new products has high cost and risk. The costs originate several expenses such as: investment in research, engineering, market research, market development and product testing. As far as failure risks are concerned, research shows that they vary from $33 \%$ to $46 \%$ depending on the sector, industry or product nature. However, the risks and expenses in the development of new products may be minimized through good management of these issues.

\section{COMPETITIVITY}

We can define competitivity as the organization's ability to allocate and administrate resources for growing markets ; the organization's capacity of increasing its participation in the market and profits ; A company's capacity of strengthening its position in the market.

The factors which most affect the companies' competitivity, according to Di Serio(1998) are :

\section{Figure 1 - Factors affecting competitivity}

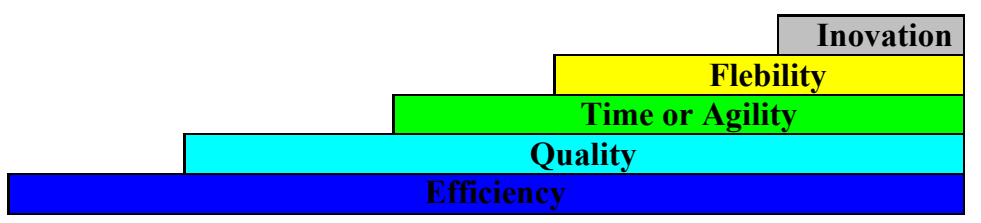

Di Serio(1998)

Efficiency : the organization's capacity of achieving its goals with the best cost-benefit relation possible as using the available resources.

Quality : the organization's capacity of offering a product or service according to the specifications and/or needs demanded by the client.

Time : the organization's capacity of responding promptly to the new market requisites.

Flexibility : the organization's capacity of offering a wide variety of products and services at the customization level, which within the limits responds to each client's individual needs, that is, mass customization.

Innovation : the organization's capacity of conceiving ideas, practices, products and/or services which are perceived as new by the market. 
According to Fine (1999: 23) the great challenge in the organizations' competitivity is that "No leadership is unreachable, no kingdom is unbeatable. In fact the higher the clockspeed, the shorter the kingdom. The sustainable advantage is a typical concept in a low clockspeed situation ; the temporary advantage is the predominant concept in environments with high clockspeed. And the evolving speed is accelerating almost everywhere ".

According to Venkatraman ( 1994 ), see figure 2 , technology is used strategically by the organizations, offering competitivity differences . Considering that, Venkatraman (1994) defined the use of technology as strategic tool in five levels :

\section{Figure 3 - Information Technology as Strategic Tool}

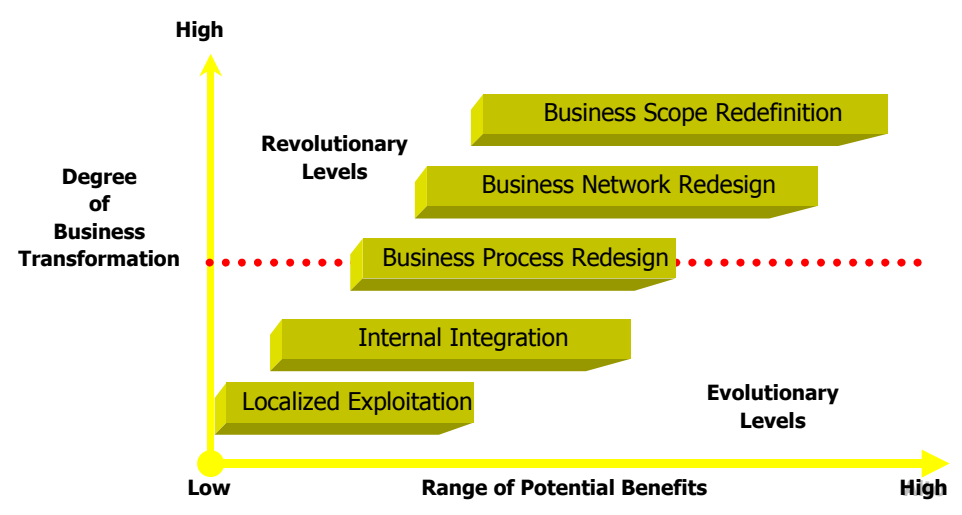

Venkatraman(1994)

Localized Exploration : at this level the use of technology happens discreetly in localized processes.

Internal Integration : at this level the company promotes the integration with suppliers

Reengineering of Processes : technology is being used to change the business .

Reengineering of Business Networks : technology is used to redefine the business network.

Redefinition of the Business Scope : technology is used to redefine the business scope, exploring new opportunities .

\section{METHODOLOGY}

Two methodologies were used in this work. The first one is case study, due to basic research questions, absence of control over behavioral events and emphasis on contemporary events. The study considered and respected several aspects, conditions, recommendations, components and requisites defined by various authors such as Yin (1994). The second methodology was bibliographic raising in order to compose the theoretical reference and use of secondary data from reliable sources.

The methodology application of the case study was carried out through interviews and used a protocol which was specifically devised for this purpose. This protocol took into consideration the need of knowing the organization and its integration processes with the partners . 


\section{THE CASE}

The case in study concerns the company EMBRAER, which actuates in the air transport market.

These are some data about the company:

Established in 1969

Business Scope : project, development, manufacturing, commercialization and maintenance of civil and military aircrafts .

Headquarters : São José dos Campos, SP

Employees : approximately 9,000

Facilities : approximately 254,000 square meters

The company, originally controlled by public capital, was privatized on September, $7^{\text {th }}, 1994$ through auction. Its current controlling group is composed by the following main shareholders : Group Bozano, Previ - Caixa de Previdência Privada do Banco do Brasil and Sistel ( Fundação Telebrás de Seguridade Social ) .

\section{THE COMPANY AND THE SECTOR}

The regional aviation market expanded considerably in the late 70 s due to the deregulation of the commercial aviation sector in the United States.

The so called deregulation, promoted in the Reagan government made it easier for new companies to be created and consequently caused the appearance of a large number of new regional airlines, in a market previously ruled by the major airlines. These small and medium sized new airlines started to explore a market niche which was not served by the major companies : the regional transport between less populated urban centers. The offer of this new service with attractive prices generated an increase in demand in the North-American air transport. Regular short flights started to join towns which were not served by regular air transport. A new market was created for connection flights linking small towns to big cities, the so called hubs .

The great majority of regional airlines started their operations using mainly small and medium sized turbopropeler airplanes. As there was no specific equipment for this market at that time, the companies started operating with airplanes specially adapted for this purpose.

The Bandeirante, manufactured by Embraer, whose original project was designed to transport military troops, was adapted to operate in the regional transport.

The turbopropelers ruled the aviation scenario during the $70 \mathrm{~s}$ and $80 \mathrm{~s}$. At that time there were not jet reactors with specific cunsumption characteristics necessary to the commercial operation in this market. The small jet airplanes which existed then were used in the executive transport market. 
In the late $80 \mathrm{~s}$, however, the advances in technology of turbofan engines which permitted the appearance of lower consumption jet engines, and the increase in demand noticed in the NorthAmerican regional aviation, made the engine and airplane manufacturers decide to invest in equipment in order to reach that market. This is when the two biggest competitors in that segment appeared : the Canadair Regional Jet ( CRJ), produced by Bombardier in Canada and the Embraer's ERJ-145.

The airlines started to prefer jet to turbopropeler airplanes due to the passengers preference for the first ones .Jet planes are considered safer by the passengers even though there is no concrete evidence of this perception.

The main factor which increased the sales of jet planes was certainly the new generation planes' capacity of presenting competible operational costs with the market, and even equivalent or lower than the old turbopropelers'. This fact associated to the bigger comfort of jet planes and the passengers' preference changed the world of the regional aeronautical industry .

The following graph shows a comparison between the operational costs of ERJ-145 and turbopropeler airplanes in the same category. We can notice a balance in the shorter distances and a clear advantage of the ERJ-145 in the longer distances .

\section{The clients Value Model}

Analysis conducted by Embraer indicate that these main factors are considered in their clients' Value Model :

Product Characterisitcs : High "delivery “, High technology, Operation safety and Operational flexibility

Cost Characteristics : smallest "DOC" possible and financing availability

Other Characteristics : Market availability ( time to market ), Delivery time , Efficiency of support services ( replacing parts, maintenance, repairs ) and Speed in solving operational problems .

\section{Tendencies and Critical Success Factors}

The following tendencies were recently identified by Embraer in their business sector : Reduction of Manufacturing and Development Cycles ; Intensive Use of Information Technology ; Extension of the Integrated Development concept through oriented structure to projects (Integrated Product Teams and Design Build Teams ); Redesign of manufacturing processes ("lean manufcturing ") ; Adoption of integrated management systems ( ERP) and Integration of processes with clients and suppliers.

Based on the clients'value model and on the tendencies the company elected as Critical Success Factors : The Reduction of production and development cycles as condition to reach the market with suitable price and in the correct time ; Smallest operational cost possible for the client and Improvement of post sales services so as to "faithfulize" clients and guarantee its position in the market. 


\section{INTEGRATED DEVELOPMENT AS STRATEGY}

In the aeronautical industry as in some other productive sectors which work with highly technologic products, the development of a new product is probably the activity which most adds core value to the clients, contributes to the company's strategic positioning and at the same time contains the highest risk level .

For their clients, the airplane is a vital income generator resource because the capacity of the company to provide the transport service and consequently generate operational profits depends on it .

An airplane's total operation cost includes the investment amortization with its purchase or the monthly amount paid in the leasing form, the crew workforce cost and other costs related to its use such as fuel, maintenance, etc. The product development affects all these areas. The decisions made along the process will influence all the cost factors involved in the operation of an aircraft, being able to determine its success or failure from the economic and operational point of view.

The company's flexibility and rapidity in developing new products is another critical factor for its clients. The ability of projecting and supplying an airplane which meets clients' expectations before the competitors do, allows the company to be a fast mover and consequently take a slice of the new growing segment of the regional aviation market .

\section{INTEGRATED DEVELOPMENT AND THE ERJ-145}

The development of the ERJ-145, regional jet for 50 passengers, proved to be extremely successful. Based on market research which indicated the regional airlines' need for a bigger airplane, they evaluated which would be the main operational requisites of their prospect key-clients through interviews and contact with specialized personnel in the sector of operations and maintenance of those clients. They also asked about the preferences of the final consumers ( passengers ) concerning the airplanes' interior features. In addition to that some airlines' technical teams were invited to contribute with suggestions during the concept and development phase.

The company started to use the main fundaments of product integrated development in the new airplane's project. Interdisciplinary teams were formed aiming to ensure the involvement of all participants from the various enterprise processes. These teams leaders would meet frequently with clients and suppliers to ensure better integration. For the first time there was the extensive use of systems CAD/CAM ( Computer Assisted Design / Computer Assisted Manufacturing ) as a way to reduce the development cycle and cost, ensuring at the same time the perfect adjustment of the final product to its project requisites and to the clients'demands .

This strategy, focussed on the market demands and on integrated development proved to be successful . In its first year of production the ERJ-145 managed to achieve $45 \%$ of the sales of 50 -seat jets . At the end of 1999, only three years after the first delivery, more than 170 airplanes were working in 15 different airlines spread throughout four continents .

Nowadays the company occupies a leading position in the world aeronautical industry . With backlog ( orders ) reaching the amount of US\$ 21 billion ( data from June 2000 ), Embraer was considered one of the main participants of this market and started to be respected not only as manufacturer, but also as technology generator. 
The company currently produces the ERJ 145 and the ERJ 135 jets with capacity for 50 and 37 passengers respectively, besides the BEM 120 Brasília, a turbopropeler for 30 passengers . Also in production phase the BEM 145 AEW\&C airwatch airplane and the BEM 145 RS remote sensoring airplane, both for the SIVAM project. In June 2000 Embraer employed about 9,000 people and had already delivered more than 5,300 airplanes to its clients during its 30 years of existence.

Embraer is developing three new airplanes for the regional aviation market, the ERJ 170 and the ERJ 190-100 and ERJ-200, with capacity for 70, 90 and 108 passengers respectively. Besides those the company is also finishing the development of the BEM 314 Super Tucano, light attack airplane for the Brazilian Air Force and

The ERJ 140 jet derived from the ERJ 145 with capacity for 44 passengers. They are also developing new versions of the AM-X, a combat airplane built in consortium with Italian companies, and of the airwatch and remote sensoring airplanes, based on the ERJ 145 platform. The company has also recently started the development of a new executive airplane, the Legacy, based on the ERJ 135 platform.

It is interesting to observe that Embraer's products strategy is focussed on the extension of a concept for various products, using as much as possible the same platform or a platform derived from a pre-existing one with consequent reduction of development costs and gains in the production scale.

As we can see, Embraer has an expressive number of proceeding projects. Its accelerated growth and the multiplication of its project increased the complexity of product development administration. It was necessary to adopt a dedicated strategy so as to keep meeting the demands of the market in which it actuates.

\section{SUPPLIERS’ PARTICIPATION IN PRODUCTS DEVELOPMENT}

As most aeronautical companies, Embraer intensively uses resources from third parts in its projects. The company also has domain and internal control over its products'whole life cycle , since the inicial definitions phase when the product starts to be designed, until the post-sale support phase. However, for economic and strategic reasons, it relies on suppliers and risk partners for the systems and components project which do not represent core competences in the organization.

The suppliers and risk partners' participation not only in the parts and pieces supply, but also in the development of airplanes parts and systems is a tendency which has increased in this sector. The aim is to concentrate efforts and investments on those areas which are considered core competences in the organization and reduce the amount and the investments risks necessary to the project of a new airplane.

The use of risk partnerships in projects started in Embraer with the ERJ 145. The company adopted this system as a deliberate strategy, due to the economical crisis it was going through in the beginning of the project. The strategy proved successful and had good results.

This concept was expanded in the project of new planes, the ERJ 170 and the ERJ 190 which will have several structural components, fuselage sections, systems and equipment projected and supplied by risk partners. 
Embraer is working with risk partners located in three continents, including Kawasaki in Japan, Sonaca in Belgium, Latécoère in France and Gamesa in Spain. Among the partners in the USA are General Electric , Hamilton/Sundstrand, Honeywell and C\&D Interiors.

The risk partership system demands great integration between the companies participating in the project. In the initial definitions phase, which requires intense information exchange through personal contact, the teams work co-located in a single environment. In further phases, however, they start working in different places. At this moment computational tools are indispensable in order to maintain integration. The intensive use of information technology is fundamental. The processes should be alligned so as not to have discontinuity.

Although the intensive use of risk partnerships and suppliers in the producs development is undoubtedly advantageous, it is very important that the interface control and coordination mechanisms be developed. The development process management in this case becomes even more complex and asks for suitable tools, methods, processes and structures.

\section{CONCLUSIONS}

Analysing the case in study based on the critical aspects of a new product development and in terms of competitivity, we may observe the following aspects :

Embraer managed to administrate and divide the risk of a high cost product development through risk partnership. These partnerships did not involve only the financial issue, but the participation in the product development itself.

The project administration and coordenation, which is the part which makes its execution possible as well as the advantages for the parts, continued with the company and is one of its great competences nowadays.

The product development process through partnerships demands a dynamic and evolutive structure.

The product integrated development through partnerships demanded a redesign of the processes and of the organization in itself.

Technology is used intensively as support to various phases of the project and as support and structure of communication and integration between the project participants.

A radical change in the way of interacting with the market made the company to recover from a difficult financial position. In the past, the company simply sold products technically perfect in despite of the market's interests. Nowadays the company listens the market, even inviting it to give its opinion, and then manufactures the products. This strategy follows the new products development principles.

Through the perception of a change in the clients' behavior, that is, an interest for jet airplanes for shorter distances, the company identified a great market opportunity.

In terms of competitivity and analysing initially through the Di Serio model (1998 ), the company currently competes in : 
Cost: offering a product which is operationally cheaper for the client

Quality: concerning the product's reliability itself and the operational services offered by the company or its partners.

Agility / Time: reducing the products' production time .

Flexibility: the company allows the client to personalize/customize several airplane components.

Innovation: designing and producing new products to the market.

Analysing the aspect competitivity based on technology, showed by Venkatrman (1994 ), the company uses technology to :

Carry out the whole internal and external integration process .

Redesign the business process and in a last stage redesign its business network.

Without the use of technology as part of the competitivity strategy the company would not have managed to achieve its position on the market.

Although the case under study is successful, we can observe that the development of a product in a risk partnership environment makes the company reflect upon its several dimentions, among which we can highlight: processes, technology, people and organizational structure.

Considering the restrains of an only case study, the work shows that the innovation process and the development of new products depends on a good understanding of the market, that is, of the client, and on a deep knowledge of the organization competences. Therefore, only later on, the various strategies and managements form are conceived.

\section{Artigo recebido em 25/09/2001. Aprovado em 07/11/2001.}

\section{BIBLIOGRAPHY}

BRUCE, Margaret, BIEMANS, Wim G., Product Development: Meeting The Challenge of The Design-Marketing Interface, New York: Jonh Wiley, 1995

DI SERIO, Luiz Carlos, Notas de Aula da Disciplina de Administração da Produção do Curso de Mestrado e Doutorado da EAESP-FGV, São Paulo: EAESP-FGV 1998

FINE, Charles H., Mercados em Evolução Contínua: Conquistando a Vantagem Competitiva num Mundo em Constante Mutação, Rio de Janeiro: Editora Campus, 1999.

PORTER, Michael E. Vantagem competitiva: criando e sustentando um desempenho superior. Rio de Janeiro: Editora Campus, 1996.

ROSENAU, Milton D., GRIFFIN, A., CASTELliON, G. A., ANSCHUETZ, Ned F., The PDMA Handbook of New Product Development, New York: Jonh Wiley, 1996. 
URBAN, Glen L.,HAUSER, Jonh R., Design and Marketing of New Products, NJ : Prentice Hall 1993.

VENKATRAMAN, N., IT-Enabled Business Transformation: From Automation to Business Scope Redefiniton, Sloan Management Review, Winter 1994.

YIN, R. K. Case Study Research: design and methods. Newburry Park: Sage Publications, 1989. 